\author{
ПРОФСПІЛКОВИЙ РУХ У ПЕРШІЙ \\ ЧЕХОСЛОВАЦЬКІЙ РЕСПУБЛІЦІ В ПЕРІОА \\ 31918 ПО 1924 PP. ${ }^{\circ}$
}

\author{
ПІКОВСЬКА Т.В., \\ кандидат історичних наук, \\ стариий викладач кафедри права \\ Вінницький національний \\ аграрний університет \\ (м. Вінниця)
}

\begin{abstract}
Проаналізовано економічний розвиток та політичний устрій Чехословаччини після закінчення Першої світової війни. Зосереджено увагу на особливостях функиіонування профспілок у республіці. Визначені окремі характерні риси профспілкового руху - фрагментація та вплив політичних партій. Висвітлено прочес здійснення профспілками своїх безпосередніх функиій посередництва між великим капіталом і робітниками, покращення становища працюючих. Охарактеризовані способи здійснення чехословаџькими профспілками ицих функиій, які можна розділити на три групи: прямі акції, інструменти соціального примирення, допоміжні заходи. Відзначено, що вплив профспілок протягом 1918-1924 рр. як виразника інтересів робітників суттєво зріс. Про ие свідчить статистика виграних трудових спорів $і$ успішних страйків прачівників. Проте фрагментація профспілок, яка з часом ще більше посилилась, не дозволила зробити діалог між робітником і державою більш рачіональним, щзо з часом призвело до зниження інтенсивності страйкового руху та зменшення рівня довіри до профспілок у робітничому середовищі. Головною причиною иього явища була розрізненість чехословащького суспільства, зумовлена національною, релігійною та політичною неоднорідністю.
\end{abstract}

Ключові слова: Перша Чехословацька республіка, профспілки, страйк, бойкот, колективний договір, соціальна допомога, підприємство.

Табл: 2. Літ: 13.

\title{
TRADE UNION MOVEMENT IN THE FIRST CHECHOSLOVATSKIY REPUBLIC IN THE PERIOD FROM 1918 TO 1924
}

\author{
PIKOVSKA Tatyana, \\ Candidate of Historical Sciences, \\ Senior Lecturer of the Department of Law, \\ Vinnytsia National Agrarian University
}

(Vinnytsia)

The economic development and political structure of Czechoslovakia after the end of the First World War are analyzed. The attention is focused on the peculiarities of the functioning of trade unions in the republic. Specific features of the trade union movement are defined-fragmentation and influence of political parties. The process of implementation by trade unions of its direct functions - mediation between large capital and workers, improvement of the status of employees - is highlighted.The methods of Czechoslovak trade unions' implementation of these functions are described, which can be divided into three groups: direct actions, instruments of social reconciliation, auxiliary measures. It is noted that the influence of trade unions during 1918-1924 as a speaker of the interests of the workers increased significantly. This is evidenced by the statistics of the won labor disputes and successful strikes of employees. However, the fragmentation of trade unions, which eventually intensified, did not allow a dialogue between the worker and the state more rational, which eventually led to a decrease in the intensity of the strike movement and a decrease in the level of trust in trade unions in the working environment.The main cause of this phenomenon was the disparity of the Czechoslovak society due to national, religious and political heterogeneity.

Key words: First Czechoslovak republic, trade unions, strike, boycott, collective agreement, social assistance, enterprise.

Tabl.: 2. Lit.: 13. 


\section{http://efm.vsau.org/ \\ ПРОФСОЮЗНОЕ ДВИЖЕНИЕ В ПЕРВОЙ ЧЕХОСЛОВАЦКОЙ РЕСПУБЛИКЕ В ПЕРИОД С 1918 ПО 1924 гг.}

\section{ПИКОВСКАЯ Т.В., кандидат исторических наук, стариий преподаватель кафедры права, Винницкий национальный аграрный университет}

(2.Винница)

Проанализировано экономическое развитие и политическое устройство Чехословакии после окончания Первой мировой войны. Сосредоточено внимание на особенностях функционирования профсоюзов в республике. Определены отдельные характерные черты профсоюзного движения фрагментация и влияние политических партий. Освещзается процесс осуществления профсоюзами своих непосредственных функиий - посредничества между крупным капиталом и рабочими, улучшение положения работающих. Охарактеризованы способы осуществления чехословачкими профсоюзами этих функций, которые можно разделить на три группь: прямые акции, инструменты сочиильного примирения, вспомогательные мероприятия.Отмечено что влияние профсоюзов в течение 1918-1924 г2. как выразителя интересов работников существенно вырос. Об этом свидетельствует статистика вынгранных трудовых споров и успешных забастовок работников. Однако фрагментация профсоюзов, со временем еще больше усилилась не позволила сделать диалог между рабочим и государством более раџиональным, что со временем привело к снижению интенсивности забастовочного движения и снижение уровня доверия к профсоюзам в рабочей среде. Главной причиной этого явления была разрозненность чехословачкого общества обусловленая начиональной, религиозной и политической неоднородностью.

Ключевые слова: Первая Чехословацкая республика, профсоюзы, забастовки, бойкот, коллективный договор, социальная помощь, предприятие.

Табл.: 2. Лит.: 13.

Постановка проблеми. Після розпаду Австро-Угорської імперії на ії руїнах виник цілий ряд нових держав. Однією з них стала Перша Чехословацька республіка (далі-ЧСР), яка проіснувала 1918 по 1938 рр. Демократичний устрій нової держави став сприятливим грунтом для розростання цілої мережі профспілкових товариств. Тогочасне чехословацьке суспільство мало багато ліній розмежування строкатий національний склад, відмінності між містом і селом, велика кількість політичних партій, які в свою чергу створювали велику кількість різноманітних організацій, в тому числі і профспілкових. Все це створювало унікальну, властиву лише міжвоєнній Чехословаччині картину розвитку профспілкового руху. Цей досвід може бути корисним для будь-якої держави в контексті створення функціональної моделі співпраці між індивідуумом та багатонаціональним суспільством.

Аналіз останніх досліджень і публікацій. Джерельну базу дослідження становлять переважно праці чеських науковців. Вони поділяються на дві групи: праці сучасників досліджуваного періоду та праці сучасних чеських науковців. До перших належать дослідження Котека Й. [1]. та Оберхолла А.[2], в яких детально описані статистичні відомості про зміни чисельності та складу профспілкових організацій. До другої групи належать праці сучасних чеських істориків - Чапки Ф. [3], Карніка 3. [4], Ракошніка Я. [5;6], Казімірової В. [7]. У цих роботах здійснено критичний аналіз діяльності профспілок та їх впливу на тогочасне чехословацьке суспільство. Окрему групу джерел становлять закони Першої ЧСР, які регулювали діяльність профспілкових організацій [8;9;10;11]. На жаль, в українській історіографії немає досліджень, присвячених профспілковому руху у міжвоєнній Чехословаччині. Проте українські науковці здійснювали дослідження закономірностей розвитку профспілок [12] та функціонування Гентської страхової системи [13], які допомогли встановити окремі особливості профспілкового руху в досліджуваний період.

Формулювання цілей статті. Метою статті є наукове дослідження профспілкового руху у Першій ЧСР в період з 1918 по 1924 рр., зокрема загальних особливостей профспілкового руху, діяльності найбільших профспілкових організацій та взаємодії профспілок і держави.

Виклад основного матеріалу дослідження. Після утворення незалежної Чехословацької держави постало питання про реформування діяльності профспілкових організацій. Визначальну роль відігравало те, що суспільно-політичний устрій Першої ЧСР суттєво відрізнявся від устрою Австро-Угорської імперії. Тим не менш, в економічному контексті Чехословаччину можна в значній мірі вважати спадкоємицею Австро-Угорщини. На iï території знаходилось 70\% виробничих потужностей Габсбурзької монархії [4, с.35]. 
Проте, промисловість Чехословаччини перебувала на значно нижчому рівні, ніж у провідних країнах Західної Свропи. Значною проблемою була нерівномірна концентрація промислових об'єктів. Промислово розвинутими територіями були Північна Чехія, Моравія, Сілезія, а також Центральна і Західна Богемія у той час, коли Південна Богемія, більша частина Словаччини та вся Підкарпатська Русь зовсім не мали промислових підприємств.

В умовах необхідності у розбудові промисловості робітники були важливою частиною соціальної бази новоствореної держави. Важливу роль у співпраці робітників із владою Чехословаччини відігравали профспілки. Вони представляли специфічні інтереси окремої категорії громадян (працюючих), що відрізнялись від інтересів, які представляли політичні партії або громадські організації. Профспілки не мали політичної влади, але безумовно мали політичний вплив. Порівняно з довоєнною Австро-Угорщиною роль профспілок сягнула нового, якісно вищого рівня. У той час, коли у міжвоєнний період у світі відбувалась значна радикалізація робітничого руху, в Чехословаччині виникли ключові інституції посередництва між державною владою та працюючими громадянами.

Відповідно до даних, які свого часу опублікував М. Вольф у 1913 р., 73\% працюючих були членами профспілки [10, s.58]. Особливістю тогочасних профспілок, яка збережеться і в період існування ЧСР, була підпорядкованість частини 3 них політичним партіям. Зокрема, Партія Національних Соціалістів контролювала 18,5\% профспілок, 8,5\% контролювали християнські демократи. Після Першої світової війни внаслідок бойових дій кількість членів профспілок зменшилась на $30 \%$ [10, с.59]. таблиці 1.

Розвиток профспілкового руху у Першій ЧСР порівняно з іншими державами показаний у

Кількість осіб залучених до профспілок в різних державах світу в 1921 p.

\begin{tabular}{|l|c|c|c|}
\hline \multicolumn{1}{|c|}{ Держава } & $\begin{array}{c}\text { Кількість } \\
\text { населення }\end{array}$ & $\begin{array}{c}\text { Кількість членів } \\
\text { профспілок }\end{array}$ & $\begin{array}{c}\text { Відсоток членів профспілок відносно } \\
\text { загальної кількості населення }\end{array}$ \\
\hline Чехословаччина & 13613172 & 1976923 & 14,52 \\
\hline Франція & 39209766 & 1046788 & 2,67 \\
\hline Угорщина & 7980143 & 342577 & 4,29 \\
\hline Німеччина & 59855966 & 12595947 & 21,04 \\
\hline Польща & 27178690 & 822777 & 17,28 \\
\hline Австрія & 6526661 & 1128125 & 4,09 \\
\hline США & 105711000 & 5179227 & 6,45 \\
\hline Швеція & 5904489 & 381018 & 13,85 \\
\hline Велика Британія & 47361591 & 6559933 & \\
\hline
\end{tabular}

Джерело: Oberschall A. Odborové organisace zaměstnanecké v rep. Československé: statistická studie za léta 1913-1922 / Albin Oberschall. - Praha: Státní úrad statistický, 1924. - 435 s.

Згідно з даними наведеними у таблиці за кількістю членів профспілки Чехословаччина перебувала на 6-му місці. Певним недоліком, який не дозволяє побачити всю картину охоплення профспілками населення республіки $\epsilon$ відсутність відомостей, які показують відсоток представників робітничих професій залучених до профспілки.

Структура профспілкового руху була чітко визначеною та мала ієрархічний характер. Найбільш впливове становище мали великі профспілки, які підтримували політичні партії. Ця підтримка могла бути як відкритою так і прихованою. У середині кожної профспілкової організації існувала ціла мережа невеликих профспілкових організацій, які називались профспілкові департаменти і діяли на окремих підприємствах. Формально їхня діяльність була незалежною від центру. Також були невеликі профспілки, які не перебували під впливом жодної великої профспілкової організації. На відміну від профспілок, фінансованих політичними партіями, вони мали незначний політичний вплив на місцях.

У 20-х рр. найбільшою профспілковою організацією в республіці була Чехословацька Профспілкова Спілка (далі - ЧПС). У добу післявоєнного революційного піднесення до ії лав вступили 850 тисяч осіб. Вона була електоральною опорою однієї з найбільших партій Першої ЧСР Чехословацької соціал-демократичної робітничої партії (далі - ЧСДРП). Ключовою фігурою у керівництві ЧПС був голова організації Рудольф Тайерле, який з 1919 по 1939 рік був депутатом Національних Зборів. Варто зауважити, що оскільки ЧСДРП у перші роки існування Першої ЧСР була правлячою партією, профспілкова організація мала реальний вплив на суспільні настрої [3, с. 24]. 
Ситуація змінилась, коли в лавах ЧСДРП відбувся розкол. У квітні 1921 р. від партії відокремилось радикальне марксистське крило, яке утворило Комуністичну Партію Чехословаччини (далі - КПЧ). Цей розкол послабив ЧПС, оскільки новостворена партія відразу ж утворила свою профспілкову організацію - Міжнародний Союз Профспілок ( далі - МСП). Попри намагання ЧПС дистанціюватись від цього розколу і оголосити про свій політичний нейтралітет, профспілка на декілька років втратила свій статус найвпливовішої в республіці.

МСП стала найбільш ліворадикальною профспілковою організацією у міжвоєнній Чехословаччині. Через приналежність до КПЧ вона отримала ще одну, неофіційну назву - Червона профспілка. На відміну від ЧПС, яка офіційно не визнавала свій зв'язок із соціал-демократами, МСП відверто говорила про те, що $\epsilon$ комуністичною профспілковою організацією, найвище керівництво якої знаходиться в більшовицькій Росії. Значну частину членів профспілки становили колишні радикально налаштовані члени ЧПС, а також прихильники німецьких партій лівого спрямування [3, с. 27].

Другою найвпливовішою профспілковою організацією була Чехословацька Робітнича Спілка (далі - ЧРС). Вона перебувала під опікою Чехословацької соціалістичної партії ( далі - ЧСП). Головою профспілкової організації був заступник голови виконавчого комітету партії Алоїс Тучний. На відміну від ЧПС вона мала яскраво виражену націоналістичну позицію, тому 98\% іiі членів складали чехи і словаки [3, с. 28]. Як і партія, профспілка надавала перевагу відстоюванню національних інтересів, а не професійних. Тому в перші роки існування Чехословаччини ЧРС поступалась за чисельністю ЧПС.

Третьою найбільшою групою профспілок були християнські профспілки, які об'єднували робітників католицького віросповідання. Вони перебували під впливом правого крила Чехословацької Народної Партії ( далі - ЧНП) на чолі з Яном Шрамеком. Християнські профспілки виражали консервативну політичну позицію. Після закінчення Першої світової війни в середовищі невеликих християнських профспілок розпочались об'єднавчі процеси так само, як і у християнсько-соціалістичних та католицьких партій республіки. На початку 20-х рр. була створена Загальнодержавна християнсько-соціалістична профспілкова організація із центром у м. Брно. Вона прагнула об'єднати всі християнські профспілки республіки. Проте через розкол у лавах ЧНП об'єднання не відбулось. Фактично, до середини 20-х рр. утворилась мережа локальних невеликих профспілкових осередків християнського спрямування [7, с.12].

Крім великих профспілкових об’єднань, у республіці була значна кількість невеликих профспілок. Частина з них належала до невпливових політичних партій. Проте були й такі, які мали виключно професійний характер. Прикладом є профспілки державних службовців, вчителів, залізничників і навіть трунарів. Ці профспілки була значно гірше фінансовані, ніж профспілки політичних партій і. як правило, створювались в промислово нерозвинутих віддалених від центру районах. Тим не менш, вони продовжували існувати до кінця Першої ЧСР.

Характеризуючи чехословацький профспілковий рух, варто визначити його особливості. Чеський історик Я. Ракошнік відзначає, що для профспілок Першої ЧСР була характерна фрагментація - утворення великої кількості маленьких профспілок і небажання об'єднуватись у великі, загальнодержавні профспілкові організації [10,s.59]. Фрагментація профспілок була не лише чехословацькою проблемою. Переглядаючи дані, наведені у таблиці 2, ми можемо зробити висновки, що така ж ситуація складалась і у всіх інших європейських країнах.

Таблиия 2

Фрагментація профспілкового руху в різних країнах світу у 1923 р.

\begin{tabular}{|l|c|c|c|c|c|c|}
\hline \multicolumn{1}{|c|}{ Держава } & $\begin{array}{c}\text { Амстердамський } \\
\text { інтернаціонал } \\
\text { профспілок }\end{array}$ & $\begin{array}{c}\text { Християнсько- } \\
\text { соціальні } \\
\text { профспілки }\end{array}$ & $\begin{array}{c}\text { Анархістські } \\
\text { профспілки }\end{array}$ & $\begin{array}{c}\text { Комуністичні } \\
\text { профспілки }\end{array}$ & Різні & Всього \\
\hline Чехословаччина & 324179 & 126049 & - & 89941 & 747608 & 1504923 \\
\hline Франція & 757847 & 125000 & - & 350000 & 163000 & 1495847 \\
\hline Угорщина & 176401 & 15141 & - & - & - & 191542 \\
\hline Німеччина & 6293359 & 1300000 & - & 100000 & 1300000 & 9193359 \\
\hline Польща & 369811 & 120000 & - & - & 280000 & 769811 \\
\hline Австрія & 896763 & 79377 & - & - & 101500 & 1117192 \\
\hline США & - & - & 58000 & - & 2865979 & 3600000 \\
\hline Швеція & 313022 & - & 37000 & - & 50000 & 400000 \\
\hline Велика Британія & 4328235 & - & - & - & 1076765 & 5405000 \\
\hline
\end{tabular}

Джерело: Oberschall A. Odborové organisace zaměstnanecké v rep. Československé: statistická studie za léta 1913-1922 / Albin Oberschall. - Praha: Státní úřad statistický, 1924. - 435 s. 
Проте ми також бачимо, що в Чехословаччині рівень фрагментації найвищий. У республіці, як і в інших європейських державах, була найбільше представлена міжнародна профспілкова організація «Амстердамський інтернаціонал профспілок». У той же час, якщо в інших державах ця профспілкова організація об'єднувала більшість працюючих, то в ЧСР - лише $20 \%$.

У середовищі лідерів профспілок часто лунали заяви про необхідність об’єднання і створення загальнодержавної профспілкової організації для більш ефективного відстоювання інтересів працюючих. На заваді цьому об'єднанню стали дві визначальні особливості Першої ЧСР багатонаціональність та багатопартійність. Яскравим прикладом є перемовини, які кілька років велись між керівництвом двох найбільших чехословацьких профспілок ЧПС і ЧРС. Об'єднання так і не вдалось досягнути через політичні суперечності соціал-демократів та націонал-соціалістів, які фактично керували профспілками [3, с.40].

Важливим аспектом розуміння характеру профспілкового руху у міжвоєнній Чехословаччині $є$ здійснення профспілковими організаціями своїх безпосередніх функцій. Головними функціями профспілок у міжвоєнному світі були посередництво між великим капіталом і робітниками та об'єднання працівників із метою покращення умов праці та збільшення заробітної плати. Способи здійснення чехословацькими профспілками цих функцій можна розділити на три групи: прямі акції, інструменти соціального примирення, допоміжні заходи.

До категорії прямих акцій можна передусім віднести страйки. Частота та інтенсивність такої форми відстоювання інтересів працюючих збільшувалась у період перебування більшої кількості профспілок під впливом лівих сил. У середньому в період із 1919 по 1924 рр. кожен робітник страйкував 10 днів на рік ( для порівняння в 1899-1903 pp. - 17 днів, в 1909 - 1913 pp. - 27 днів на рік). За період 1919-1924 pp. 8 тис. 618 робітників взяли участь у страйках [1, с.117].

До прямих акцій профспілок можна також віднести бойкот та саботаж, які в перші роки існування республіки набули значної популярності. У межах цих акцій робітники або не виконували роботу, перебуваючи на робочому місці, або виконували мінімальний обсяг.

Серед інструментів соціального примирення в першу чергу варто виділити колективні договори. Міжвоєнна доба стала піком висунення спільних колективних вимог працівниками до роботодавців. Колективні угоди стали тією правовою основою, яка допомагала працівникам у вирішенні трудових спорів із роботодавцем.

Історія колективних трудових договорів у чеських землях сягала часу задовго до утворення Першої ЧСР. Перший такий контракт був укладений у Цислейтанії в 1896 році між власником і працівниками друкарні $[1, \mathrm{c.86}]$.

Принцип таких колективних угод полягав у тому, щоб прописати умови праці, які не гарантувались чинним законодавством. Спочатку вони укладались переважно для регулювання питань оплати праці. У міжвоєнний період збільшилась не лише кількість контрактів, але й якість. Прописувалось значно більше положень, ніж у попередні часи. До 1919 р. профспілки брали участь у переговорах про підписання 1087 колективних договорів, які регулювали роботу 946409 працівників [10, с.59]. Вже наприкінці 20-х рр. ця цифра зросла вдвічі.

Наступним інструментом соціального примирення, який застосовували профспілки, стало створення підприємницьких комітетів. Ці органи самоврядування робітників почали активно виникати після завершення Першої світової війни. Було два типи таких організацій підприємницькі комітети та підприємницькі ради. Вони відрізнялись за назвою, але були тотожні за своєю суттю. Діяльність підприємницьких рад була легалізована законом №143/1920 [9]. Основною їх функцією мав бути контроль за належним розподілом між робітниками частки прибутку від підприємства. Частка прибутку становила 10\% від чистого прибутку підприємства. Відповідно до закону підприємницькі ради скликались на підприємствах чисельністю не менше 100 робітників. У їхньому складі було 7 осіб. 3 них троє - робітники підприємства, один - службовець із відділу кадрів або канцелярії, решту визначав власник підприємства [5, с.213].

Одночасно із попереднім законом був прийнятий закон №144/1920, який визначав порядок створення підприємницьких комітетів у гірничодобувній промисловості. Згідно з ним підприємницькі ради засновувались на підприємствах цієї галузі, де працювало постійно від 20 робітників [9].

Діяльність підприємницьких комітетів була затверджена на рік пізніше, у серпні 1921 р. законом №330/1921. Вони створювались на підприємствах, на яких працювали понад 30 найманих працівників. Залежно від кількості працівників, підприємницький комітет складався із 3-20 осіб [10].

Функції комітетів і рад були передусім наглядові та координаційні. Жодного серйозного впливу на становище робітників вони не мали, лише створювали ілюзію робітничого самоврядування. 


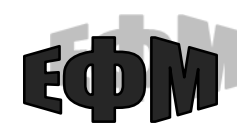

http://efm.vsau.org/

До допоміжних заходів належить соціальна підтримка робітників, яку здійснювали профспілки. Корені соціально підтримувальної діяльності профспілок у чеських землях сягають ще XIX ст., коли в Цислейтанії у 80-х рр. сформувались фонди допомоги робітникам та їхнім сім'ям у випадку безробіття, хвороби, інвалідності або смерті [5, с.113].

У міжвоєнний період у Чехословаччині покращилось соціальне забезпечення робітників із боку держави. Законом №63/1918 було введено допомогу безробітним [8]. Закон №221/1924 установлював обов'язкове страхування на випадок хвороби та інвалідності [11]. Проте видатки на соціальну сферу були недостатніми. Порівняно з довоєнним періодом у 1921 р. вони знизились на $28 \%$ [7, с.23]. Тому в 20-х рр. профспілки були вагомим інструментом соціального захисту робітників. Вони активно займались оздоровленням працівників, а також опікою колишніх робітників похилого віку.

У 1924 р. Чехословаччина приєдналась до світової Гентської системи страхування, яка полягала у наданні прямих субсидій членам профспілок із спеціально створеного комунального фонду. Система забезпечувала фіксованою допомогою кожного безробітного в доповнення до суми, яку він отримав від профспілки. Відповідно до Гентської системи страхування від безробіття субсидії надавались щорічно та вираховувались на основі допомог, сплачених за минулий рік. Однак, в економічно депресивні роки подібна система стикалась із великими труднощами. Резерви не робились, і в разі збільшення запитів про компенсацію, фонди втрачали свої фінансові запаси [12, с.8].

У чехословацькій версії Гентської системи страхування працівника здійснювалось у його профспілці, а держава надавала допомогу у вигляді фіксованої одноразової виплати. Профспілкові юристи наголошували на власній відповідальності працівника за свою безпеку і на необхідності вчасно сплачувати членські внески. Зростання кількості членів профспілок не допомогло впоратись із кількістю виплат, які були зумовлені безробіттям в умовах економічної кризи. Фактично, в середині 20-х рр. більшість профспілкових фондів збанкротувала [3, с. 58].

Таким чином, можна зробити висновок, що вплив профспілок протягом 1918-1924 pp. як виразника інтересів робітників суттєво зріс. Про це свідчить статистика виграних трудових спорів i успішних страйків працівників. Проте фрагментація профспілок, яка 3 часом ще більше посилилась, не дозволила зробити діалог між робітником і державою більш раціональним, що 3 часом призвело до зниження інтенсивності страйкового руху та зменшення рівня довіри до профспілок у робітничому середовищі. Головною причиною цього явища була розрізненість чехословацького суспільства, зумовлена національною, релігійною та політичною неоднорідністю. Хвиля об'єднання профспілок відбудеться лише після Другої світової війни, коли профспілки активно входять у політичне життя країни і утворюють Революційний профспілковий рух. У подальшому детального вивчення потребує проблема взаємодії чехословацьких профспілок із закордонними партіями й організаціями та вплив цієї взаємодії на розпад Першої ЧСР.

\section{Список використаних джерел}

1. Kotek J. Odborové hnutí zaměstnanců: teorie a prakse odborového hnutí, vývoj a stav odborového hnutí zaměstnanců v Československu a v cizině. Praha, 1930. 287 s.

2. Oberschall A. Odborové organisace zaměstnanecké v rep. Československé: statistická studie za léta 1913-1922. Praha: Státní úřad statistický, 1924. 435 s.

3.Čapka F. Odbory v českých zemích v letech 1918-1948. Praha, 2008. 288 s.

4. Karnik Z. České země v éře První republiky (1918-1938). Díl první, Vznik, budování a zlatá léta republiky (1918-1929). Praha: Libri, 2003. 545 s.

5. Rákosník J. Sociální stát v Československu: právněinstitucionální vývoj v letech 1918-1992. Praha: Auditorium, 2012. 416 s.

6. Rákosník J. Odborové organizace v počátcích Československa. Praha, 2007. 302 s.

7.Kazimourová V. Vliv odborů na podobu personální práce v meziválečném Československu. Praha, 2017. $71 \mathrm{~s}$.

8. Sbírka zákonů a nařízení státu československého Praha, 1918. URL: http://www.psp.cz/eknih/ 1918ns/ps/tisky/t0444_00.htm. (дата звернення: 11.04.2019)

9. Sbírka zákonů a nařízení státu československého. Praha, 1920. URL: http://www.psp.cz/eknih /1920ns/ps/tisky/t0444_00.htm. (дата звернення: 11.04.2019)

10. Sbírka zákonů a nařízení státu československého .Praha, URL: 1921 http://www.psp.cz/ eknih/1921ns/ps/tisky/t0444_00.htm. (дата звернення: 11.04.2019)

11. Sbírka zákonů a nařízení státu československého.Praha, URL:1924. http://www.psp.cz/ eknih/1924ns/ps/tisky/t0444_00.htm. (дата звернення: 11.04.2019) 
12. Севрюков Д.Г. Розвиток соціальної держави у Бельгії. Науковий вісник Міжнародного гуманітарного університету. Серія : Юриспрудениія. 2014. №10. С. 8-10.

13. Левчук К.І. Основні напрями діяльності Федерації профспілок України в умовах запровадження ринкових відносин (1992-1996 рр.). Етнічна історія народів Свропи. 2012. №37. С. 12-17.

\section{References}

1. Kotek, J. (1930). Odborové hnutí zaměstnanců: teorie a prakse odborového hnutí, vývoj a stav odborového hnutí zaměstnanců v Československu a v cizině [Trade union movement of employees: theory and practice of trade union movement, development and status of trade union movement of employees in Czechoslovakia and abroad]. Praha: Sociální ústav republiky ČSR [in Czechoslovakia].

2. Oberschall, A. (1924) Odborové organisace zaměstnanecké v rep. Československé: statistická studie za léta 1913-1922 [Employee Trade Unions in the Czechoslovak Republic: Statistical Study for 1913-1922]. Praha: Státní úr̆ad statistický [in Czechoslovakia].

3. Čapka, F. (2008) Odbory v českých zemich v letech 1918-1948 [Trade unions in the Czech lands in 1918-1948]. Praha [in Czech Republic].

4. Karnik, Z.(2003) České země v ére První republiky (1918-1938). Díl první, Vznik, budování a zlatá léta republiky (1918-1929) [Czech lands in the era of the First Republic (1918-1938). Part One, The Birth, Building and Golden Years of the Republic (1918-1929)]. Praha [in Czech Republic].

5.Rákosník, J.,\& Tomeš, I.(2012) Sociálni stát v Československu: právněinstitucionální vývoj v letech 1918-1992 [Social State in Czechoslovakia: Legal-Institutional Development in 1918-1992]. Praha [in Czech Republic].

6. Rákosník J. Odborové organizace v počátcích Československa (2007) [Trade unions at the beginning of Czechoslovakia]. Praha [in Czech Republic].

7. Kazimourová, V. (2017) Vliv odborů na podobu personálni práce v meziválečném Československu [Influence of trade unions on the form of personnel work in interwar Czechoslovakia]. Praha [in Czech Republic].

8. Sbírka zákonů a nařizení státu československého [Collection of laws and decisions of the Czechoslovak Parliament]. Retrieved from http://www.psp.cz/eknih/1918ns/ps/tisky/t0444_00.htm. / [in Czech Republic].

9. Sbírka zákonů a nařízení státu československého [Collection of laws and decisions of the Czechoslovak Parliament]. Retrieved from http://www.psp.cz/eknih/1920ns/ps/tisky/t0444_00.htm. / [in Czech Republic].

10. Sbírka zákonů a nařizení státu československého [Collection of laws and decisions of the Czechoslovak Parliament]. Retrieved from http://www.psp.cz/eknih/1921ns/ps/tisky/t0444_00.htm. / [in Czech Republic].

11. Sbírka zákonů a nař́zení státu československého [Collection of laws and decisions of the Czechoslovak Parliament].Retrieved from http://www.psp.cz/eknih/1924 ns/ps/tisky/t0444_00.htm. / [in Czech Republic].

12. Sevryukov, D.H. (2014) Rozvytok sotsial'noyi derzhavy u Bel'hiyi [The development of a social state in Belgium]. Naukovyy visnyk Mizhnarodnoho humanitarnoho universytetu. Seriya: Yurysprudentsiya. Scientific Herald of the International Humanitarian University. Series: Jurisprudence. 10, 8-10. [in Ukrainian]

13. Levchuk,K.I. (2012) Osnovni napryamy diyal'nosti Federatsiyi profspilok Ukrayiny v umovakh zaprovadzhennya rynkovykh vidnosyn (1992-1996 rr.). [The main directions of activity of the Federation of Trade Unions of Ukraine in the conditions of the introduction of market relations (1992-1996)]. Etnichna istoriya narodiv Yevropy. Ethnic history of the peoples of Europe. 37, 2-12. [in Ukrainian]

\section{Інформація про автора}

ПІКОВСЬКА Тетяна Валентинівна - кандидат історичних наук, старший викладач кафедри права, Вінницький національний аграрний університет ( 21008, м. Вінниця, вул. Сонячна, 3, e-mail: Tetiana261285@i.ua)

PIKOVSKA Tetiana Valentinivna - Candidate of Historical Sciences, Senior Lecturer of the Department of Law, Vinnytsia National Agrarian University (21008, Vinnytsia, 3, Solyaschyna St., e-mail: Tetiana261285@i.ua)

ПИКОВСКАЯ Татьяна Валентиновна - кандидат исторических наук, старший преподаватель кафедры права, Винницкий национальный аграрный университет (21008, г. Винница, ул. Солнечная, 3, e-mail: Tetiana261285@i.ua) 